\title{
Family ownership and risk: the role of family managers
}

\section{Carlotta D'Este and Marina Carabelli}

\begin{abstract}
Purpose - This study aims to investigate the relationship between family managers and firms' risk levels in a context characterized by low investor protection and firm opacity. Specifically, this paper examines whether the level of risk faced by firms is affected by family shareholders' ownership stake and activism.

Design/methodology/approach - Corporate governance data were hand-collected for a sample of 90 Italian listed companies and 540 observations from the year 2018. Regression analysis was then used to test the research hypotheses.

Findings - This study provides evidence of a positive association between active family ownership and risk faced by sampled firms. This study also finds that the number of inside directors is negatively correlated with firms' risk-taking. Overall, the results confirm family managers' influence on firms' risk choices and show consistency with theoretical arguments in favor of hiring professional managers to guide family-owned firms.

Practical implications - Practical implications emerge from the study findings. First, family owners should consider to hire a larger number of professional managers to support firms' wealth maximization and retention and to reduce default risks. Second, investors should take into account the firms' board of directors and management composition to better assess the investments risk level. Finally, the positive correlation between active family owners and systematic risk suggests the opportunity for regulators to improve the legal requirements related to minority directors to increase their effectiveness and, therefore, minority shareholders' protection.

Originality/value - This study extends the literature on the association between ownership structure and firms' risk levels, showing the effect of family managers on firms' risk levels. Besides, to the best of the authors' knowledge, no previous study investigates professional executives' influence on risk when family ownership prevails.
\end{abstract}

Keywords Active shareholders, Family ownership, Family managers, Risk-taking

Paper type Research paper

\section{Introduction}

The global financial crisis has raised concerns about the level of risk faced by firms, thus emphasizing the role of corporate governance mechanisms as a means to manage risk levels (Tao and Hutchinson, 2013). In this regard, the extant literature has highlighted the importance of the monitoring function played by outside and independent directors, given their ability to supervise the business behavior of executives (Deutsch et al., 2011; Kim et al., 2014).

According to agency theory, the conflict between managers and shareholders reduces firms' performance and influences managerial risk-taking (Jensen and Meckling, 1976; Alam and Shah, 2013).

To mitigate this conflict, in contexts characterized by dispersed ownership, shareholders must align the agents' interests with their own through corporate governance mechanisms. When concentrated ownership prevails, however, control rights are centralized in the hands of large shareholders, thus influencing executives' risk-taking choices
Carlotta D'Este is based at the Dipartimento di Scienze Economiche e Sociali, Università Cattolica del Sacro Cuore-Campus di Piacenza e Cremona, Piacenza, Italy. Marina Carabelli is a PhD student at Università Cattolica del Sacro CuoreCampus di Piacenza e Cremona, Piacenza, Italy.

Received 11 September 2021 Revised 4 November 2021 Accepted 6 January 2022

(c) Carlotta D'Este and Marina Carabelli.Published by Emerald Publishing Limited. This article is published under the Creative Commons Attribution (CC BY 4.0) licence. Anyone may reproduce, distribute, translate and create derivative works of this article (for both commercial and non-commercial purposes), subject to full attribution to the original publication and authors. The full terms of this licence may be seen at http://creativecommons.org/licences/by/4.0/ legalcode 
(Jensen and Murphy, 1990; Wright et al., 1996; Shleifer and Vishny, 1997). From this perspective, family ownership magnifies these effects, as family members not only have the ability to closely supervise executives but are also often members of the board of directors and thus actively participate in the decision-making process (Oba et al., 2010).

Previous studies investigating the relationship between family ownership and firms' risk levels did not provide conclusive results (Anderson and Reeb, 2003; Anderson et al., 2009; Zahra, 2005; Lee et al., 2018; Rajverma et al., 2019).

We believe that inconsistency can be ascribed to the relationship between corporate governance and both country-level and firm-level characteristics, as according to previous literature, "different agency problems [arise] in different geographical areas" (EIKelish, 2018 , p. 254). At the country level, several factors are found to exert an influence on corporate governance structures and mechanisms. Based on Hofstede's (1983) national cultural dimensions, some authors (Morck et al.,1999; John et al., 2008) report that regulatory, institutional and political factors such as a country's level of investor protection and corporate opacity, the degree of ownership concentration and the development of market for corporate control significantly affect the effectiveness of corporate governance practices, thus impacting firms' strategic choices and performance.

Specifically, when low investor protection and concentrated ownership prevail, large shareholders' potential to extract private benefits of control is enhanced, thanks to close monitoring of executives and active participation in strategic decision-making (Holderness, 2003). Furthermore, a scarcely developed market for corporate control enhances the relevance of internal governance mechanisms (Mishra and Kapil, 2017), while firms' opacity increases the information asymmetry to the detriment of minority shareholders (Fosu et al., 2017).

These circumstances can, in turn, both prompt and intertwine with firm-level factors that affect the agency problem, such as large shareholders' activism, insiders' potential for entrenchment and portfolio diversification (Wright et al., 1996). This seems particularly true for family owners because of their long-term orientation and strong involvement in the business (Zahra, 2005; Di Pietra et al., 2008).

In light of the above, we suggest that inconsistent findings on the correlation between family ownership and firms' risk levels could be explained by considering both the characteristics of the external environment in which firms' operate and those of family ownership.

Despite the well-stated association between corporate governance and country- and firmspecific attributes, their link with corporate risk-taking appears to be investigated by very few studies referring specifically to financial industry entities (Gaganis et al.,2019).

Our paper, thus, contributes to existing literature by examining the association between family ownership and firms' risk in the Italian context, assuming that its specific firm- and country-level characteristics, namely, low investor protection and opacity, as well as prevailing family members' management, have a positive effect on risk levels.

On the one hand, under such conditions, not only family owners are found to effectively exert an influence on firms' executives, addressing their choices consistently with their own preferences but they also prefer risk-taking corporate strategies because of their need to ensure the family's wealth maximization (Spong and Sullivan, 1998).

On the other hand, as family managers are found to be less professionally skilled than hired managers, their involvement in the decision-making process could lead to nonoptimal business strategies (Robinson and Pearce, 1984; Rossi et al., 2018), thus affecting firms' risk levels.

We, therefore, investigate the association between active family shareholders and risk-taking. In addition, assuming that when family ownership prevails, executives' 
decision-making is lobbied by active owners, we analyze the association between the number of inside directors and firms' risk level.

The results show that when investor protection is low and family owners participate in firms' management, the presence of active ownership increases firms' risk level. Additionally, as Italian family owners tend to be board members, this circumstance confirms their ability to address executive choices through the exercise of voting power and lobbying practices (Wright et al., 1996; Shleifer and Vishny, 1997). Interestingly, we also find that the higher the number of inside directors is, the lower the risk faced by firms.

Building on previous research findings, this study adds to the extant literature, as it helps clarify the association between corporate governance and risk and shows that country- and firm-level characteristics may affect the way the ownership structure is related to firms' risk. Next, we provide a preliminary response to the call for future research of Wright et al. (1996), as the authors suggested that to shed light on the impact of large investors on firms' risk, a distinction between active and passive shareholders should be made. Finally, to the best of our knowledge, no previous study has investigated the influence exerted by executives on firms' risk levels when active family ownership prevails.

The remainder of the paper is organized as follows. Section 2 reviews the related literature and develops our hypotheses. Section 3 describes the sample and the research design. Section 4 presents the empirical results and Section 5 concludes the paper.

\section{Literature review and hypotheses development}

\subsection{Corporate governance and risk-taking}

Compared to studies focused on corporate governance and firm performance, the existing literature on the association between corporate governance and the level of risk faced by firms is relatively small (Alam and Shah, 2013; Chang et al., 2015; Alfiero and Venuti, 2016). Studies on the topic mainly investigate the influence exerted by the board of directors and by the ownership structure on corporate risk-taking, showing mixed results (Morck et al., 1999; Nguyen, 2011; Mathew et al., 2016; Birindelli et al., 2020).

Under agency theory, the need for alignment between shareholders' and managers' interests is well-known (La Porta et al., 2000; Berkman et al., 2009). From this perspective, the board of directors represents a key corporate governance tool because of its advising and monitoring functions and outside directors are considered better supervisors than inside directors (Chang et al., 2015), as their greater independence from the chief executive officer allows for more effective control over insiders' actions.

In terms of executives' risk-taking choices, it is argued that the misalignment between shareholders' and managers' goals translates into different degrees of risk propensity (Abinzano et al., 2020; Ongsakul et al., 2021), which raises questions regarding the association between corporate governance mechanisms and risk.

Studies investigating the effect of board characteristics show moderate consensus on the effectiveness of the nonexecutives' monitoring functions in lessening firms' risk. For example, Tao and Hutchinson (2013) found that having experienced and professionally qualified members on the risk committee results in closer monitoring of the firms' risk level. Additionally, more independent and diversified boards and more frequent board meetings are negatively associated with risk levels (Eling and Marek, 2014; Chong et al., 2018; Elamer et al., 2018; Hatane et al., 2019; Bhat et al., 2020; Hurley and Choudhary, 2020). Also, Chang et al. (2015) stated that when directors' compensation is linked to corporate performance, the risk levels faced by firms decrease.

Conversely, evidence is provided of no significant relation between risk-taking and board independence and size, as well as audit committees independence (Alam and Shah, 2013). 
Similarly, Deutsch et al. (2011) found that outside directors' stock option compensation increases firms' risk-taking.

According to some authors (John et al., 2008), the inconsistent results can be explained by the twofold way in which corporate governance mechanisms can affect firms' risk levels. On the one hand, under agency theory, it can be assumed that stronger corporate governance processes may reduce executives' discretion and, thus, lessen the opportunity for excessive risk-taking (Eling and Marek, 2014). On the other hand, better corporate governance structures could lead managers to undertake riskier activities to enhance firms' profitability in alignment with shareholders' interests.

These mixed theoretical possibilities can be better understood by considering that the effectiveness of corporate governance mechanisms is affected by firm- and countryspecific factors (Raithatha and Popli, 2021), as well as by insiders' characteristics and preferences (Wright et al., 1996).

At the country level, it is argued that the degree of shareholder protection (John et al., 2008) and national culture (Hofstede, 1983; Yi, 2011; Li and Harrison, 2008; Gaganis et al., 2019) can affect corporate risk choices. In this regard, Morck et al. (1999) report that countries' institutional development and, more specifically, investor protection and government honesty affects stock prices. Additionally, a country's requirements for mandatory firm disclosure are found to impact firms' risk (Feng et al., 2017; Fosu et al., 2017).

At the firm level, the ownership structure affects the way shareholders act to align insiders' interests and behavior. In this regard, it must be noted that for firms with concentrated ownership, large shareholders can lobby executives through their voting power and heightened monitoring activities (Shleifer and Vishny, 1997; Dyck and Zingales, 2004), thus influencing strategic choices related to the firms' risk level and, therefore, overshadowing outside directors' role (Alshirah et al., 2020).

Furthermore, insiders' risk-taking is influenced by different factors, such as their total wealth portfolios, pecuniary and nonpecuniary benefits and the potential for entrenchment (Wright et al., 1996). In this regard, it is argued that the appointment of large shareholders and family owners to the board of directors influences the risk faced by firms, guiding hired managers toward risk levels desired by owners (Spong and Sullivan, 1998).

\subsection{Ownership concentration, family ownership and firms' risk levels}

Based on the evidence of shareholders' preference for raising firms' profits and value by taking on risky projects (Paligorova, 2010), prior literature has largely investigated the association between concentrated ownership and corporate risk-taking, with no conclusive results (Spong and Sullivan, 1998; lannotta et al., 2007; Laeven and Levine, 2009; Magalhaes et al., 2010; Dong et al., 2014).

Wright et al. (1996) found that as equity ownership levels increase, corporate risk-taking decreases. Eling and Marek (2014) reported that a higher number of blockholders negatively affects corporate risk-taking choices. Likewise, Weinstein and Yafeh (1998) found that bank ownership discourages firms from investing in risky projects. Similar results were shown by Alfiero and Venuti (2016) and by Vu et al. (2020), estimating a negative association between domestic controlling investors and risk levels.

However, other studies found opposite results. Barry et al. (2011) reported that for publicly held banks, changes in the ownership structure are not relevant to corporate risk levels. Similarly, Saunders et al. (1990) found higher risk-taking behavior in owner-controlled banks than in managerially controlled banks, as reported by Gürsoy and Aydoğan (2002) and Dhillon and Rossetto (2015). 
Considering family ownership, the extant literature highlights some distinctive features that affect corporate risk-taking decisions. First, because of family owners' involvement in the business' matters and their ability to control managers, family firms represent "an ideal organizational form where the objectives of the owner and the firm are aligned" (Zahra, 2005 , p. 26). Second, family owners have a stronger long-term orientation than other categories of shareholders due to the need to ensure the continuity of the firm and to maximize family wealth.

These circumstances are found to be associated with conflicting effects. On the one hand, it is argued that family owners favor more conservative strategies to limit the risk of firm failure and increase the likelihood of handover (Abinzano et al., 2020). On the other hand, the aim of handing down the business to the next generation leads family owners to fully exploit entrepreneurial opportunities (Nguyen, 2011) and take on riskier projects to increase the firm's value and competitive advantage (Zahra, 2005). Furthermore, this tendency seems to be strengthened by owners' unique values, motivation, commitment to the business and opportunity costs of monitoring (Randøy and Goel, 2003).

In addition, as family owners' portfolios tend to be less diversified, this condition can alternatively lead to lower risk-taking, when family owners feel to bear excessive uncertainty or to higher risk levels in cases of low diversification (Anderson and Reeb, 2003; Anderson et al., 2009; Nguyen, 2011).

Nevertheless, some authors (Wang et al., 2007; Sonfield and Lussier, 2009) maintain that due to their lack of expertise and knowledge, family owners are worse managers than professional ones and fail to formulate appropriate corporate strategies, especially in uncertain and turbulent external environments (Robinson and Pearce, 1984; Dyer, 1989; Shrader et al., 1989; Yusuf and Saffu, 2005), therefore exposing family businesses to greater levels of risk (Berry, 1998). This seems to be especially true for family firms operating with low investor protection, where family members must remain involved in running the business because of agency conflicts (Burkart et al., 2003).

Most previous studies focused on the association between family ownership and firm performance, reporting mixed results (McConaughy et al., 2001; Cronqvist and Nilsson, 2003; Barth et al., 2005; Villalonga and Amit, 2006; Nguyen, 2011).

Concerning the relationship with risk-taking, some authors provide evidence that family ownership negatively impacts corporate risk-taking. Kim and Cho (2021) report an association between large family blockholders and low firm risk levels. Accordingly, Rajverma et al. (2019) documented that family ownership concentration and family control reduce firms' risk, and Paligorova (2010) and Gadhoum and Ayadi (2003) found that Canadian family shareholders avoid risk-taking as their ownership increases.

In contrast, Nguyen (2011) finds a positive association between family ownership and firms' risk levels, explained by family owners' greater ability to drive firms toward value-enhancing and riskier investments and away from diversification strategies. Similar results were found by Geeta and Prasanna (2016) and by Zahra (2005). Additionally, Lee et al. (2018) identified a "U-shaped" relationship between family owners and firms' risk levels, as the undertaking of risky projects tends to increase as the ownership stake held by family members grows.

We suggest that inconclusive research findings may be related to both firm- and countrylevel factors. While low shareholder protection is found to enhance the potential for family owners to put pressure on managers and to address their actions toward their own goals, their degree of activism and their board membership enable them to participate in longterm key investment decisions (Zahra, 2005). This circumstance is strengthened by firms' opacity, which reinforces owners' ability to influence insiders' decision-making in accordance with their preferences. 
Furthermore, at the firm level, we assume that the distinctive features of family businesses impact risk, as family owners not only aim to maximize the firm's value but also face issues related to professional and managerial skills.

Therefore, we suggest that Italian family-owned listed companies face higher risk levels. In fact, the Italian context is characterized not only by weak financial market development due to low shareholder protection and high firm opacity but also by high involvement of family members in the business (Volpin, 2002; Di Pietra et al., 2008; Matias Gama and Rodrigues, 2013).

In addition, Wright et al. (1996) stated that conflicting results concerning the association between concentrated ownership and corporate risk can be ascribed to the different influences exerted by active and passive large investors, as only active investors would act as monitors of insiders. Hence, our first hypothesis is as follows:

H1. In the Italian context, active family ownership is positively related to firms' risk levels.

\subsection{Board of directors and firms' risk levels}

The extant research on the association between the composition of the board of directors and firms' risk levels largely focuses on outside directors. Concerning executives, previous literature mainly investigates the effects of managerial incentives and ownership on risk choices (Downs and Sommer, 1999; Chang et al., 2015; Yeh, 2017).

On this topic, Berger et al. (2014) explore the relationship between executive characteristics and firms' risk levels, finding that inside directors do influence risk-taking choices, given their central role in determining firms' strategies and operations. Previous studies report that for family firms, insiders are closely controlled and lobbied by family owners (Shleifer and Vishny, 1997; Schulze et al., 2003), thus weakening the effectiveness of outside directors' roles (Alshirah et al., 2020). Furthermore, family owners tend to be members of the board of directors and thus entrenched in their position (Anderson et al., 2003; Nguyen, 2011).

Assuming that for family-controlled firms, greater alignment between insiders' and owners' goals affects corporate risk-taking (Spong and Sullivan, 1998), our second hypothesis follows:

H2. In the Italian context, the number of inside directors is positively related to firms' risk levels.

\section{Sample selection and research design}

Our study analyzes 90 Italian family-owned listed companies. Starting with 357 Italian listed companies, those pertaining to the financial sector were excluded as well as those with missing corporate governance data. We also excluded companies with a two-tier or one-tier system. Our sample then comprised 108 listed companies. We subsequently selected family-owned companies. Thus, the final sample includes 90 entities and 540 observations from 2018.

As we aim to investigate the impact of active family ownership on risk, a firm's risk level represents the dependent variable. According to previous studies (Tao and Hutchinson, 2013; Kim and Cho, 2021), we use the levered beta for firms' risk, as previous findings indicate that it is related to ownership concentration (Rossetto and Staglianò, 2012) and we are interested in testing the ability of family owners to effectively face external environmental events.

Our independent variables include family ownership, family owners' activism $(H 1)$ and the number of inside directors (H2). 
To test our hypotheses, we used the following multivariate linear regression model:

$$
\text { BETA }=\beta_{1} \text { INTERACTION }+\beta_{2} \text { INSDIR }+\beta_{3} \text { Tobin's } q+\beta_{4} \text { LNASSETS }+\varepsilon
$$

Based on previous studies (Zahra, 2005), we assume that, given Italian context peculiarities, the larger the ownership stake of the majority shareholder is and the more active family owners are, the higher the risk faced by firms will be. We, therefore, use a proxy for the degree of family owners' activism, simultaneously considering their ownership stakes and their degree of activism (INTERACTION variable). The degree of ownership concentration can be expressed as the percentage of shares owned by family members, while shareholders' activism is measured as a dummy variable equal to one when family members are appointed to the board of directors and zero otherwise. To obtain a comprehensive index, we, therefore, measure the interaction variable by multiplying the percentage of shares owned by the largest shareholder by the dummy variable. In addition, the number of executives is measured as the percentage of inside directors.

We control for firm size and based on previous findings (Morck et al., 1988; Klein et al., 2005), for firms' value, as there is no consensus on its association with firms' risk-taking. To proxy firms' value, we use Tobin's q, as many previous studies relate it to ownership structure (Hiraki et al., 2003).

Levered beta was collected from Bloomberg, while data on family ownership and on the degree of activism were hand-collected from companies' corporate governance reports and from Bureau van Dijk's database Orbis.

Finally, financial statement data and Tobin's q were collected from Orbis.

\section{Results}

\subsection{Descriptive statistics and correlation analysis}

As shown in Figure 1, according to the Italian Stock Exchange classification, the majority of sampled firms operate in the industrial goods and services sector (47\%). The remaining companies operate in the media (18\%) and oil and gas industry (18\%), followed by travel and leisure (12\%) and consumer products and services (5\%).

\section{Figure 1 Industry}

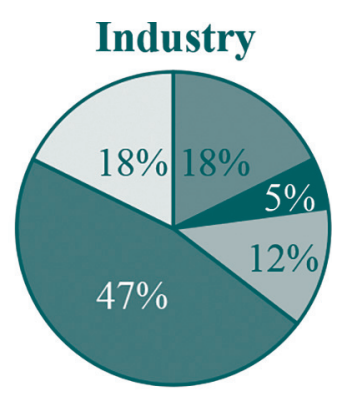

$\square$ Media

Consumer products and services $\square$ Oil \& Gas

Industrial goods and services $\square$ Travel and leisure 
Table 1 shows the descriptive statistics. The average family ownership stake amounts to $47 \%$, ranging from $3.89 \%$ to $100 \%$. The median value is $50 \%$ and the asymmetry index shows that the majority of family owners hold more than $50 \%$ of the sampled companies, confirming that, in Italy, family owners tend to be majority shareholders. In this regard, it must be noted that family owners are board members for approximately $70 \%$ of the sampled companies, consistent with previous findings (Saito, 2008).

Accordingly, average shareholder activism, measured as a dummy variable equal to 1 when owners are appointed to the board of directors and 0 otherwise, equals $69 \%$, as reported by several authors (Villalonga and Amit, 2006; Abinzano et al., 2020) and shown by Figure 2 .

On average, appointed inside directors amount to 2.77 , while the median value is 3 , so that the average percentage of inside directors equals 33\%, showing consistency with Italian legal prescriptions.

Focusing on control variables, descriptive statistics show an average value of the total assets amounting to $€ 3868,703$ and a median value of $€ 457,779$. Because of the high variability of total assets, to measure firm size, we used the natural logarithm of total assets when running the regression, according to previous literature (Berkman et al., 2009; Raithatha and Popli, 2021).

The average value of Tobin's $q$ is 0.64 , while the median is 0.44 .

The independent variable, levered beta, amounts on average to 0.76 , thus showing a high level of risk; however, this value is lower than the average value measured for listed companies.

Table 2 shows the Pearson's correlation between the main variables for all the sampled firms. The correlation analysis shows a significant negative association between levered beta and the number of inside directors ( -0.246 at the $5 \%$ level), suggesting that when the number of inside directors increases, the systematic risk faced by firms is expected to decrease.

Table 1 Descriptive statistics

\begin{tabular}{lccccccrr} 
Variables & Mean & Median & SD & Min. & Max. & Interquartile range & Asym. index & Kurtosis \\
\hline Levered Beta & 0.7799 & 0.78 & 0.33711 & -0.31 & 1.58 & 0.37 & 0.015 \\
Ownership. Stake & $48.29 \%$ & $51.00 \%$ & $20.11 \%$ & $3.89 \%$ & $100.00 \%$ & $29.77 \%$ & -0.876 \\
Inside Directors & 2.72 & 3 & 1.341 & 0 & 6 & 2 & -0.331 \\
Total Assets & $3,868.703$ & 457779 & $14464,390.90$ & 3,019 & 118373,000 & $1440,981.5$ & 0.411 & -0.353 \\
Tobin's q & 0.6272 & 0,44 & 0.67303 & 0.00 & 4.37 & 0.5 & 48166 \\
& & & & & & & 2.979 & 11.828
\end{tabular}

\section{Figure 2 Family owners' activism}

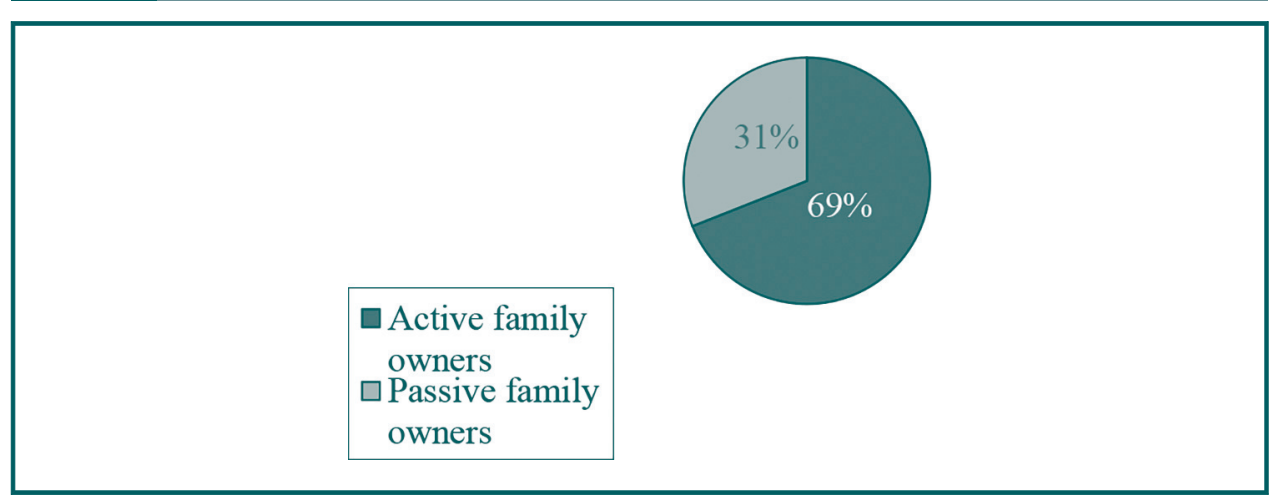

PAGE $1168 \mid$ CORPORATE GOVERNANCE $\mid$ VOL. 22 NO. 62022 
Table 2 Pearson's correlation matrix

\begin{tabular}{|c|c|c|c|c|}
\hline Variables & LEVERED BETA & INSIDIR & LNASS & TOBINSQ \\
\hline LEVERED BETA & 1 & $-0.246^{*}$ & $0.237^{*}$ & $-0.321^{* *}$ \\
\hline INSDIR & $-0.246^{*}$ & 1 & -0.052 & 0.077 \\
\hline LNASS & $0.237^{*}$ & -0.052 & 1 & -0.099 \\
\hline TOBINSQ & $-0.321^{* *}$ & 0.077 & -0.001 & 1 \\
\hline
\end{tabular}

Focusing on control variables, a negative association between levered beta and Tobin's q was found ( -0.321 at the $1 \%$ level), indicating that greater levels of systematic risk should cause a decrease in firms' value. Besides, a positive association with total assets emerges (0.237 at the $5 \%$ level), showing that larger firms are characterized by higher risk levels.

In addition, no significant association emerges between the other variables and no evidence of multicollinearity between the study variables is found, as correlation coefficients are below 0.5 (Gujarati and Porter, 2010).

\subsection{Regression results}

The results of our hypothesis testing are reported in Table 3.

Concerning the association between active family owners and firms' risk (H1), the coefficient is positive (0.003) and statistically significant ( $p$-value 0.018). Hence, in the Italian context, active family owners are associated with higher levels of risk-taking. The evidence is consistent with previous findings reporting that family owners tend to undertake riskier but more value-enhancing projects while also confirming Wright et al.'s idea that active shareholders owning large stakes exert more influence on insiders than passive ones. Nonetheless, we suggest that given the Italian context and considering that the levered beta represents systematic risk, this supports evidence that when facing turbulent and unstable external environments, family owners' management skills prove to be insufficient to lessen firms' risk levels (Robinson and Pearce, 1984; Dyer, 1989; Wang et al., 2007).

Furthermore, our findings contrast with those of studies reporting a nonmonotonic relationship between family ownership and firms' risk-taking (Anderson and Reeb, 2003; Lee et al., 2018), as the regression results suggest that as family ownership increases, the ability to monitor and align inside directors' actions with their own interest grows. Hence, we can assume that, with poor investor protection, family owners' voting power, effective monitoring and board participation lead to a greater alignment of interests between inside directors and owners, thus confirming their ability to expropriate minority shareholders.

In addition, the results do not support $H 2$, as a negative $(-0.051)$ and statistically significant association ( $p$-value 0.036 ) between the number of inside directors and firms' risk levels is

Table 3 Firms' risk levels and active family ownership

\begin{tabular}{lccc} 
& \multicolumn{2}{c}{ LEVERED BETA } & \\
& Estimate & Standarderror & p value \\
\hline INTERACTION & 0.003 & 0.001 & 0.018 \\
INSDIR & -0.051 & 0.024 & 0.036 \\
LNASS & 0.070 & 0.006 & 0.000 \\
TOBINSQ & -0.150 & 0.049 & 0.003 \\
$R^{2}$ & 0.877 & & \\
Adjusted $R^{2}$ & 0.871 & & \\
Durbin-Watson & 2.040 & &
\end{tabular}


found. As this finding shows that a larger number of inside directors leads to lower risk levels, this seems to be consistent with previous literature stating the need for family owners to appoint professional managers to the board of directors to benefit from their greater management skills. This also supports previous findings reporting a decrease in firm value when the business is handed over to the next generations and maintaining the opportunity for family owners to hire external executives to integrate their competencies in their organization (Dyer, 1989). This could be especially true when investor protection is low and ownership is concentrated, as outside directors' monitoring is less effective (Shleifer and Vishny, 1997).

Regarding the control variables, we find a positive association between firm size and risk levels. Conversely, Tobin's q appears to be negatively related to risk, confirming previous literature that reports a negative effect of family owners on firms' value (Cronqvist and Nilsson, 2003; Barth et al., 2005) but, at the same time, supporting our explanation, according to which greater levels of risk in family businesses with active owners stem from their lack of expertise. Furthermore, as the majority of the companies in the sample are managed by the heirs of the founder, our findings also show consistency with studies reporting the negative impact of nonfounder family managers (Morck et al., 1998).

We conduct variance inflation factor (VIF) tests to ensure that our results are not affected by multicollinearity issues. Table 4 shows that the VIF for LNASSETS is the largest, at 5.195. As the value is lower than 10, there appear to be no problems of multicollinearity in the regression outputs (Kennedy, 2008).

Additionally, the findings are robust to autocorrelation, as the Durbin-Watson result is 2.040.

\section{Discussion and conclusion}

The global financial crisis has raised awareness of firms' risk levels and the factors and practices that help mitigate them. From this perspective, corporate governance mechanisms are regarded as central tools capable of influencing corporate risk assumptions.

Most prior research focused on the influence exerted on risk levels by firms' ownership structure and on the role played by the board of directors in lessening firms' risk-taking, providing inconclusive results.

Building on the existing literature, we maintain that inconsistency can be ascribed to both country- and firm-level factors, such as a country's degree of investor protection and information transparency, as well as of large shareholder activism (Spong and Sullivan, 1998; Zahra, 2005; Faccio et al., 2016).

We, therefore, investigate the association between family ownership and firms' risk levels, providing evidence that active family owners positively affect the risk faced by firms.

We suggest that this circumstance can be explained by two main factors. First, we measure risk using the levered beta, which represents systematic risk faced by firms. Therefore, the positive association between active family owners and risk levels perhaps indicates that family managers, despite their propensity to take on value-enhancing projects, may be less skilled and qualified to respond to events that are external to the organization. This

\section{Table 4 VIF test results}

VIF 
argument shows consistency with that of authors reporting that hired professionals are better managers than family founders and their heirs (Burkart et al., 2003).

Second, as the majority of sampled companies' family owners are direct descendants of the founders, we also assume that the higher risk levels faced by firms with family managers can be ascribed to the family business handover, thus confirming the findings of studies that show the negative impact of founders' heirs on firms' value and performance (Villalonga and Amit, 2006).

In addition, our results partially respond to the call for future research of Wright et al. (1996), as they prove that an influence on insiders' choices is exerted by active large shareholders.

Focusing on our second hypothesis, we find that the higher the number of inside directors is, the lower the firms' risk levels. Again, this can be interpreted considering that, with family managers, additional inside directors may be professional managers able to bring more skilled competencies to the strategic decision-making process.

We, thus, contribute to the literature in several ways. Few studies have investigated the association between active family owners and firms' risk levels and even fewer have focused on systematic risk and the ability of family managers to undertake risk-mitigating strategies. Furthermore, to the best of our knowledge, no previous study has investigated the role of inside directors in the risk faced by firms. Finally, our findings help shed light on the need for founders' heirs to appoint professional executives to bring in their expertise, thus professionalizing the family (Dyer, 1989).

Finally, consistent with findings related to our hypotheses, we find a negative association between systematic risk and firms' value, therefore confirming our assumptions about the need for family owners to integrate external directors.

Overall, our findings yield several theoretical and practical implications. First, as said before, we provide additional insight into the academic debate on the influence exerted by active family managers on firms' risk, a topic that needs further in-depth research. In addition, the study highlights the role that professional managers can play in reducing risk levels, especially those related to external events, such as economic adversity and financial crises.

Second, implications for family owners and existing and potential minority shareholders emerge as well. On the one hand, family owners - particularly the founder descendants should be aware of the risk-mitigating function of hired managers, thus considering how a larger number of professionals could support wealth maximization and retention, at the same time reducing the firm's default risk and, consequently, favoring its handover. On the other hand, findings also show how investors, when making investment decisions related to family-owned companies, should take into account corporate governance characteristics and the board and management composition to better assess the investment risk level.

Finally, results also show that considering the Italian context peculiarities, the agency theory predictions stating that concentrated ownership reduces agency costs when investor protection is low (Shleifer and Vishny, 1986) are not necessarily fulfilled because family owners' orientation toward family wealth maximization and lack of skills may result in minorities' detriment. Hence, as the controlling shareholder does not always act in the interest of all shareholders (Rossi et al., 2018) or does not have the needed professional expertise, regulators should be aware that it's not a one-size-fits-all issue and could thus introduce rules that better balance family ownership costs and benefits. Specifically, as the Italian corporate governance law requires the appointment of minority directors, their effectiveness could be mandatorily improved to increase their power in protecting minority shareholders (Merendino and Melville, 2019).

Besides, questions emerge from this study, mostly related to our conjectures. First, there are explanations underlying the positive association between risk and family ownership. 
Given the peculiarities of the Italian context, we assume that the most likely explanation lies in the lack of qualified skills when owners are involved in decision-making and strategic processes. Nonetheless, evidence on this matter could be provided by future research. Second, the relationship between the number of inside directors and risk needs to be more thoroughly explored, as we do not verify whether a greater number of inside directors is related to the hiring of external professionals. While our explanations seem intuitive and to be consistent with the negative association between firms' risk levels and value, we must acknowledge that our statistical analysis does not allow for causal inference.

Furthermore, our study suffers from several limitations. As we used only 2018 data, future research could extend the analysis to a longer time period. Additionally, our study focuses on family-owned listed companies, while more comprehensive research could compare family-owned and non-family-owned firms. Finally, we do not distinguish between executive and nonexecutive family owners appointed to the board of directors. Hence, future research could investigate whether a difference exists between the two, relating to firms' risk levels.

\section{References}

Abinzano, I., Corredor, P. and Martinez, B. (2020), "Does family ownership always reduce default risk?", Accounting \& Finance, Vol. 61 No. 3, pp. 4025-4060, doi: 10.1111/acfi.12725.

Alam, A. and Shah, S.Z. (2013), "Corporate governance and its impact on firm risk", International Journal of Management, Economics and Social Sciences, Vol. 2 No. 2, pp. 76-98.

Alfiero, S. and Venuti, F. (2016), "The impact of corporate governance on risk taking in European insurance industry", International Journal of Social, Behavioral, Educational, Economic, Business and Industrial Engineering, Vol. 10 No. 1, pp. 188-194.

Alshirah, M.H., Rahman, A.A. and Mustapa, I.R. (2020), "Board of directors' characteristics and corporate risk disclosure: the moderating role of family ownership", EuroMed Journal of Business, Vol. 15 No. 2, pp. 219-252, doi: 10.1108/EMJB-09-2019-0115.

Anderson, R.C. and Reeb, D.M. (2003), "Founding-Family ownership and firm performance: evidence from the S\&P 500", The Journal of Finance, Vol. 58 No. 3, pp. 1301-1327, doi: 10.1111/ 1540-6261.00567.

Anderson, R.C., Mansi, S.A. and Reeb, D.M. (2003), "Founding family ownership and the agency cost of debt", Journal of Financial Economics, Vol. 68 No. 2, pp. 263-285, doi: 10.1016/S0304-405X (03)00067-9.

Anderson, R.C., Duru, A. and Reeb, D.M. (2009), "Founders, heirs and corporate opacity in the United States", Journal of Financial Economics, Vol. 92 No. 2, pp. 205-222, doi: 10.1016/j.jfineco.2008.04.006.

Barry, T.A., Lepetit, L. and Tarazi, A. (2011), "Ownership structure and risk in publicly held and privately owned banks", Journal of Banking \& Finance, Vol. 35 No. 5, pp. 1327-1340, doi: 10.1016/j. jbankfin.2010.10.004.

Barth, E., Gulbrandsen, T. and Schønea, P. (2005), "Family ownership and productivity: the role of ownermanagement", Journal of Corporate Finance, Vol. 11 Nos 1/2, pp. 107-127, doi: 10.1016/j. jcorpfin.2004.02.001.

Berger, A.N., Kick, T. and Schaeck, K. (2014), "Executive board composition and bank risk taking", Journal of Corporate Finance, Vol. 28, pp. 48-65, doi: 10.1016/j.jcorpfin.2013.11.006.

Berkman, H., Cole, R.A. and Fu, L.J. (2009), "Expropriation through loan guarantees to related parties: evidence from China", Journal of Banking and Finance, Vol. 33 No. 1, pp. 141-156, doi: 10.1016/j. jbankfin.2007.11.001.

Berry, M. (1998), "Strategic planning in small high tech companies", Long Range Planning, Vol. 31 No. 3 , pp. 455-466, doi: 10.1016/S0024-6301(98)80012-5.

Bhat, K.U., Chen, Y., Jebran, K. and Memon, Z.A. (2020), "Board diversity and corporate risk: evidence from China", Corporate Governance: The International Journal of Business in Society, Vol. 20 No. 2, pp. 280-293, doi: 10.1108/CG-01-2019-0001. 
Birindelli, G., Chiappini, H. and Savioli, M. (2020), "When do women on board of directors reduce bank risk?", Corporate Governance: The International Journal of Business in Society, Vol. 20 No. 7 , pp. 1307-1327, doi: 10.1108/CG-03-2020-0089.

Burkart, M., Panunzi, F. and Shleifer, A. (2003), "Family firms", The Journal of Finance, Vol. 58 No. 5, pp. 2167-2201, doi: 10.1111/1540-6261.00601.

Chang, C.S., Yu, S.W. and Hung, C.H. (2015), "Firm risk and performance: the role of corporate governance", Review of Managerial Science, Vol. 9 No. 1, pp. 141-173, doi: 10.1007/s11846014-0132-X.

Chong, L.-L., Ong, H.-B. and Tan, S.-H. (2018), "Corporate risk-taking and performance in Malaysia: the effect of board composition, political connections and sustainability practices", Corporate Governance: The International Journal of Business in Society, Vol. 18 No. 4, pp. 635-654, doi: 10.1108/CG-05-20170095.

Cronqvist, H. and Nilsson, M. (2003), "Agency costs of controlling minority shareholders", The Journal of Financial and Quantitative Analysis, Vol. 38 No. 4, pp. 695-719, doi: 10.2307/4126740.

Deutsch, Y., Keil, T. and Laamanen, T. (2011), "A dual agency view of board compensation: the joint effects of outside director and CEO stock options on firm risk", Strategic Management Journal, Vol. 32 No. 2, pp. 212-227, doi: 10.1002/smj.876.

Dhillon, A. and Rossetto, S. (2015), "Ownership structure, voting and risk", Review of Financial Studies, Vol. 28 No. 2, pp. 521-560, doi: 10.1093/rfs/hhu071.

Di Pietra, R., Grambovas, C.A., Raonic, I. and Riccaboni, A. (2008), "The effects of board size and 'busy' directors on the market value of Italian companies", Journal of Management \& Governance, Vol. 12 No. 1 , pp. 73-91, doi: 10.1007/s10997-008-9044-y.

Dong, Y., Meng, C., Firth, M. and Hou, W. (2014), "Ownership structure and risk-taking: comparative evidence from private and state-controlled banks in China", International Review of Financial Analysis, Vol. 36, pp. 120-130, doi: 10.1016/j.irfa.2014.03.009.

Downs, D.H. and Sommer, D.W. (1999), "Monitoring, ownership and risk-taking: the impact of guaranty funds", The Journal of Risk and Insurance, Vol. 66 No. 3, pp. 477-497, doi: 10.2307/253557.

Dyck, A. and Zingales, L. (2004), "Private benefits of control: an international comparison", The Journal of Finance, Vol. 59 No. 2, pp. 537-600, doi: 10.1111/j.1540-6261.2004.00642.x.

Dyer, W.G. (1989), "Integrating professional management into a family owned business", Family Business Review, Vol. 2 No. 3, pp. 221-235, doi: 10.1111/j.1741-6248.1989.00221.x.

Elamer, A.A., AlHares, A., Ntim, C.G. and Benyazid, I. (2018), "The corporate governance-risk-taking nexus: evidence from insurance companies", International Journal of Ethics and Systems, Vol. 34 No. 4, pp. 493-509, doi: 10.1108/IJOES-07-2018-0103.

Eling, M. and Marek, S.D. (2014), "Corporate governance and risk taking: evidence from the U.K. and german insurance markets", Journal of Risk and Insurance, Vol. 81 No. 3, pp. 653-682, doi: 10.1111/ j.1539-6975.2012.01510.x

EIKelish, W.W. (2018), "Corporate governance risk and the agency problem", Corporate Governance: The International Journal of Business in Society, Vol. 18 No. 2, pp. 254-269, doi: 10.1108/CG-08-20170195.

Faccio, M., Marchica, M.T. and Mura, R. (2016), "CEO gender, corporate risk-taking and the efficiency of capital allocation", Journal of Corporate Finance, Vol. 39, pp. 193-209, doi: 10.1016/j. jcorpfin.2016.02.008.

Feng, H. Fonseka, M.M. and Tian, G.L. (2017), "Risk-taking, opportunistic earnings management and corporate opacity: evidence from China", available at: https://papers.ssrn.com/sol3/papers.cfm? abstract_id=3077910 (accessed 6 September 2021)

Fosu, S., Ntim, C.G., Coffie, W. and Murinde, V. (2017), "Bank opacity and risk-taking: evidence from analysts' forecasts", Journal of Financial Stability, Vol. 33, pp. 81-95, doi: 10.1016/j.jfs.2017.10.009.

Gadhoum, Y. and Ayadi, M.A. (2003), "Ownership structure and risk: a Canadian empirical analysis", Quarterly Journal of Business and Economics, Vol. 42 Nos 1/2, pp. 19-39.

Gaganis, C., Hasan, I., Papadimitri, P. and Tasiou, M. (2019), "National culture and risk-taking: evidence from the insurance industry", Journal of Business Research, Vol. 97, pp. 104-116, doi: 10.1016/j. jbusres.2018.12.037. 
Geeta, R. and Prasanna, K. (2016), "Impact of family ownership on idiosyncratic risk", International Journal of Corporate Governance, Vol. 7 No. 4, pp. 325-352, doi: 10.1504/IJCG.2016.082349.

Gujarati, D.N. and Porter, D.C. (2010), Essentials of Econometrics, McGraw-Hill International Edition, New York, NY.

Gürsoy, G. and Aydoğan, K. (2002), "Equity ownership structure, risk taking and performance: an empirical investigation in Turkish listed companies", Emerging Markets Finance \& Trade, Vol. 38 No. 6, pp. 6-25.

Hatane, S.E., Supangat, S., Tarigan, J. and Jie, F. (2019), "Does internal corporate governance mechanism control firm risk? Evidence from Indonesia's three high-risk sectors", Corporate Governance: The International Journal of Business in Society, Vol. 19 No. 6, pp. 1362-1376, doi: 10.1108/CG-02-2019-0071.

Hiraki, T., Inoue, H., Ito, A., Kuroki, F. and Masuda, H. (2003), "Corporate governance and firm value in Japan: evidence from 1985 to 1998", Pacific-Basin Finance Journal, Vol. 11 No. 3, pp. 239-265, doi: 10.1016/S0927-538X(03)00023-4.

Hofstede, G. (1983), "The cultural relativity of organizational practices and theories", Journal of International Business Studies, Vol. 14 No. 2, pp. 75-89, doi: 10.1057/palgrave.jibs.8490867.

Holderness, C.G. (2003), "A survey of blockholders and corporate control”, Economic Policy Review, Vol. 9 No. 1, pp. 51-64, doi: 10.2139/ssrn.281952.

Hurley, D. and Choudhary, A. (2020), "Role of gender and corporate risk taking", Corporate Governance: The International Journal of Business in Society, Vol. 20 No. 3, pp. 383-399, doi: 10.1108/CG-10-20180313.

lannotta, G., Nocera, G. and Sironi, A. (2007), "Ownership structure, risk and performance in the European banking industry", Journal of Banking \& Finance, Vol. 31 No. 7, pp. 2127-2149, doi: 10.1016/j. jbankfin.2006.07.013.

Jensen, M.C. and Meckling, W.H. (1976), "Theory of the firm: managerial behavior, agency costs and ownership structure", Journal of Financial Economics, Vol. 3 No. 4, pp. 305-360.

Jensen, M.C. and Murphy, K.J. (1990), "CEO incentives - it's not how much you pay, but how", Harvard Business Review, Vol. 68 No. 3, pp. 138-153.

John, K., Litov, L. and Yeung, B. (2008), "Corporate governance and risk-taking", The Journal of Finance, Vol. 63 No. 4, pp. 1679-1728, doi: 10.1111/j.1540-6261.2008.01372.x.

Kennedy, P. (2008), A Guide to Econometrics, Blackwell, Malden, MA.

Kim, H.S. and Cho, K.S. (2021), "The ownership of the largest family blockholders and Korean firm risk", Journal of Asian Finance, Economics and Business, Vol. 8 No. 3, pp. 287-296, doi: 10.13106/jafeb.2021. vol8.no3.0287.

Kim, K., Mauldin, E. and Patro, S. (2014), "Outside directors and board advising and monitoring performance", Journal of Accounting and Economics, Vol. 57 Nos 2/3, pp. 110-131, doi: 10.1016/j. jacceco.2014.02.001.

Klein, P., Shapiro, D. and Young, J. (2005), "Corporate governance, family ownership and firm value: the Canadian evidence", Corporate Governance: An International Review, Vol. 13 No. 6, pp. 769-784, doi: 10.1111/j.1467-8683.2005.00469.x.

La Porta, R., Lopez-de-Silanes, F., Shleifer, A. and Vishny, R. (2000), "Investor protection and corporate governance", Journal of Financial Economics, Vol. 58 Nos 1/2, pp. 3-27, doi: 10.1016/S0304-405X(00) 00065-9.

Laeven, L. and Levine, R. (2009), "Bank governance, regulation and risk taking", Journal of Financial Economics, Vol. 93 No. 2, pp. 259-275, doi: 10.1016/j.jfineco.2008.09.003.

Lee, E.J., Chae, J. and Lee, Y.K. (2018), "Family ownership and risk taking", Finance Research Letters, Vol. 25, pp. 69-75, doi: 10.1016/j.frl.2017.10.010.

Li, J. and Harrison, J.R. (2008), "Corporate governance and national culture: a multi-country study", Corporate Governance: The International Journal of Business in Society, Vol. 8 No. 5, pp. 607-621, doi: 10.1108/14720700810913278.

McConaughy, D.L., Matthews, C.H. and Fialko, A.S. (2001), "Founding family controlled firms: performance, risk and value", Journal of Small Business Management, Vol. 39 No. 1, pp. 31-49, doi: 10.1111/0447-2778.00004. 
Magalhaes, R. Urtiaga, M.G. and Tribó, J.A. (2010), "Banks' ownership structure, risk and performance", available at: https://papers.ssrn.com/sol3/papers.cfm?abstract_id=1102390 (accessed 6 September 2021).

Mathew, S., Ibrahim, S. and Archbold, S. (2016), "Boards attributes that increase firm risk - evidence from the UK", Corporate Governance, Vol. 16 No. 2, pp. 233-258, doi: 10.1108/CG-09-2015-0122.

Matias Gama, A.P. and Rodrigues, C. (2013), "The governance-performance relations in publicly listed family controlled firms: an empirical analysis", Corporate Governance: The International Journal of Business in Society, Vol. 13 No. 4, pp. 439-456, doi: 10.1108/CG-04-2011-0031.

Merendino, A. and Melville, R. (2019), "The board of directors and firm performance: empirical evidence from listed companies", Corporate Governance: The International Journal of Business in Society, Vol. 19 No. 3, pp. 508-551, doi: 10.1108/CG-06-2018-0211.

Mishra, R. and Kapil, S. (2017), "Effect of ownership structure and board structure on firm value: evidence from India", Corporate Governance: The International Journal of Business in Society, Vol. 17 No. 4, pp. 700-726, doi: 10.1108/CG-03-2016-0059.

Morck, R., Shleifer, A. and Vishny, R.W. (1988), "Management ownership and market valuation: an empirical analysis", Journal of Financial Economics, Vol. 20, pp. 293-315, doi: 10.1016/0304-405X(88) 90048-7.

Morck, R., Strangeland, D. and Yeung, B. (1998), "Inherited wealth, corporate control", working paper [209], The William Davidson Institute at the University of Michigan Business School, available at: https:// core.ac.uk/reader/7057280

Morck, R., Yeung, B. and Yu, W. (1999), "The information content of stock markets: why do emerging markets have synchronous stock price movements?", working paper [44a], The William Davidson Institute at the University of Michigan Business School, available at: https://deepblue.lib.umich.edu/ bitstream/handle/2027.42/39434/wp44.pdf?sequence=3

Nguyen, P. (2011), "Corporate governance and risk-taking: evidence from Japanese firms", Pacific-Basin Finance Journal, Vol. 19 No. 3, pp. 278-297, doi: 10.1016/j.pacfin.2010.12.002.

Oba, B., Ozsoy, Z. and Atakan, S. (2010), "Power in the boardroom: a study on Turkish family-owned and listed companies", Corporate Governance: The International Journal of Business in Society, Vol. 10 No. 5 , pp. 603-616, doi: 10.1108/14720701011085571.

Ongsakul, V., Chatjuthamard, P., Jiraporn, N. and Jiraporn, P. (2021), "Does the market for corporate control influence executive risk-taking incentives? Evidence from takeover vulnerability", Corporate Governance: The International Journal of Business in Society, Vol. 21 No. 1, pp. 62-77, doi: 10.1108/CG03-2020-0106.

Paligorova, T. (2010), "Corporate risk-taking and ownership structure", available at: www.econstor.eu/ bitstream/10419/53851/1/618958037.pdf (accessed 6 September 2021).

Raithatha, M. and Popli, M. (2021), "Persistence of past: impact of historical institutions on corporate risk taking", Finance Research Letters, p. 102195, doi: 10.1016/j.frl.2021.102195.

Rajverma, A.K., Misra, A.K., Mohapatra, S. and Chandra, A. (2019), "Impact of ownership structure and dividend on firm performance and firm risk", Managerial Finance, Vol. 45 No. 8, pp. 1041-1061, doi: 10.1108/MF-09-2018-0443.

Randøy, T. and Goel, S. (2003), "Ownership structure, founder leadership and performance in Norwegian SMEs: implications for financing entrepreneurial opportunities", Journal of Business Venturing, Vol. 18 No. 5, pp. 619-637, doi: 10.1016/S0883-9026(03)00013-2.

Robinson, R.B., Jr and Pearce, J.A. (1984), "Research thrusts in small firm strategic planning", Academy of Management Review, Vol. 9 No. 1, pp. 128-137, doi: 10.5465/amr.1984.4278109.

Rossetto, S. and Staglianò, R. (2012), "The existence of blockholders and corporate governance. Empirical evidence from US", paper presented at the 29th International Conference of the French Finance Association (AFFI), Strasbourg, available at: doi: https://ssrn.com/abstract=2079554 or doi: 10.2139/ssrn.2079554

Rossi, F., Boylan, R. and Cebula, R.J. (2018), "Financial decisions and ownership structure as control mechanisms of agency problems: evidence from Italy", Corporate Governance: The International Journal of Business in Society, Vol. 18 No. 3, pp. 531-563, doi: 10.1108/CG-01-2017-0014.

Saito, T. (2008), "Family firms and firm performance: evidence from Japan", Journal of the Japanese and International Economies, Vol. 22 No. 4, pp. 620-646, doi: 10.1016/j.jjie.2008.06.001. 
Saunders, A., Strock, E. and Travlos, N.G. (1990), "Ownership structure, deregulation and bank risk taking", The Journal of Finance, Vol. 45 No. 2, pp. 643-654, doi: 10.1111/j.1540-6261.1990.tb03709. $\mathrm{x}$

Schulze, W.S., Lubatkin, M.H. and Dino, R.N. (2003), "Toward a theory of agency and altruism in family firms", Journal of Business Venturing, Vol. 18 No. 4, pp. 473-490, doi: 10.1016/S0883-9026 (03)00054-5.

Shleifer, A. and Vishny, R. (1986), "Large shareholders and corporate control", Journal of Political Economy, Vol. 94 No. 3, Part 1, pp. 461-488, doi: 10.1086/261385.

Shleifer, A. and Vishny, R.W. (1997), "A survey of corporate governance", The Journal of Finance, Vol. 52 No. 2, pp. 737-783, doi: 10.4324/9780203940136.

Shrader, C.B., Mulford, C.L. and Blackburn, V.L. (1989), "Strategic and operational planning, uncertainty and performance in small firms", Journal of Small Business Management, Vol. 27 No. 4, pp. 45-60.

Sonfield, M.C. and Lussier, R.N. (2009), "Non-family-members in the family business management team: a multinational investigation", International Entrepreneurship and Management Journal, Vol. 5 No. 4, pp. 395-415, doi: 10.1007/s11365-009-0109-4.

Spong, K.R. and Sullivan, R.J. (1998), "How does ownership structure and manager wealth influence risk? A look at ownership structure, manager wealth and risk in commercial banks", Financial Industry Perspectives, Federal Reserve Bank of Kansas City, December, pp. 15-24, available at: www. researchgate.net/profile/Kenneth-Spong/publication/5044095_How_does_ownership_structure_and_ manager_wealth_influence_risk_a_look_at_ownership_structure_manager_wealth_and_risk_in_ commercial_banks/links/0c960527bbc8f80e4b000000/How-does-ownership-structure-and-manager-wealthinfluence-risk-a-look-at-ownership-structure-manager-wealth-and-risk-in-commercial-banks.pdf

Tao, N.B. and Hutchinson, M. (2013), "Corporate governance and risk management: the role of risk management and compensation committees", Journal of Contemporary Accounting \& Economics, Vol. 9 No. 1, pp. 83-99, doi: 10.1016/j.jcae.2013.03.003.

Villalonga, B. and Amit, R. (2006), "How do family ownership, control and management affect firm value?", Journal of Financial Economics, Vol. 80 No. 2, pp. 385-417, doi: 10.1016/j.jineco.2004. 12.005 .

Volpin, P.F. (2002), "Governance with poor investor protection: evidence from top executive turnover in Italy”, Journal of Financial Economics, Vol. 64 No. 1, pp. 61-90, doi: 10.1016/S0304-405X(02)00071-5.

Vu, V.T.T., Phan, N.T. and Dang, H.N. (2020), "Impacts of ownership structure on systemic risk of listed companies in Vietnam", The Journal of Asian Finance, Economics and Business, Vol. 7 No. 2, pp. 107-117, doi: 10.13106/jafeb.2020.vol7.no2.107.

Wang, C., Walker, E. and Redmond, J. (2007), "Explaining the lack of strategic planning in SMEs: the importance of owner motivation", International Journal of Organisational Behaviour, Vol. 12 No. 1, pp. 1-16, available at: https://ro.ecu.edu.au/cgi/viewcontent.cgi?article=2453\&context= ecuworks

Weinstein, D.E. and Yafeh, Y. (1998), "On the costs of a bank-centered financial system: evidence from the changing main bank relations in Japan", The Journal of Finance, Vol. 53 No. 2, pp. 635-672, doi: 10.1111/0022-1082.254893.

Wright, P., Ferris, S.P., Sarin, A. and Awasthi, V. (1996), "Impact of corporate insider, blockholder and institutional equity ownership on firm risk taking", Academy of Management Journal, Vol. 39 No. 2, pp. 441-463, doi: 10.2307/256787.

Yeh, T.M. (2017), "Governance, risk-taking and default risk during the financial crisis: the evidence of Japanese regional banks", Corporate Governance: The International Journal of Business in Society, Vol. 17 No. 2, pp. 212-229, doi: 10.1108/CG-02-2016-0027.

Yi, J. (2011), "Revisiting Hofstede's uncertainty -avoidance dimension: a cross-cultural comparison of organizational employees in four countries", Journal of Intercultural Communication, Vol. 21 No. 1, pp. 46-61.

Yusuf, A. and Saffu, K. (2005), "Planning and performance of small and medium enterprise operators in a country in transition", Journal of Small Business Management, Vol. 43 No. 4, pp. 480-497.

Zahra, S.A. (2005), "Entrepreneurial risk taking in family firms", Family Business Review, Vol. 18 No. 1, pp. 23-40, doi: 10.1111/j.1741-6248.2005.00028.x. 


\section{Further reading}

Cole, C.R., He, E., McCullough, K.A. and Sommer, D.W. (2011), "Separation of ownership and management: implications for risk-taking behavior", Risk Management and Insurance Review, Vol. 14 No. 1, pp. 49-71, doi: 10.1111/j.1540-6296.2010.01192.x.

Coles, J.L., Daniel, N.D. and Naveen, L. (2008), "Boards: does one size fit all?", Journal of Financial Economics, Vol. 87 No. 2, pp. 329-356, doi: 10.1016/j.jfineco.2006.08.008.

Combs, J.G., Ketchen, D.J., Jr, Perryman, A.A. and Donahue, M.S. (2007), "The moderating effect of CEO power on the board composition-firm performance relationship", Journal of Management Studies, Vol. 44 No. 8, pp. 1299-1323, doi: 10.1111/j.1467-6486.2007.00708.x.

Mathew, S., Ibrahim, S. and Archbold, S. (2018), "Corporate governance and firm risk", Corporate Governance: The International Journal of Business in Society, Vol. 18 No. 1, pp. 56-67, doi: 10.1108/CG02-2017-0024.

Wang, C.J. (2012), "Board size and firm risk-taking", Review of Quantitative Finance and Accounting, Vol. 38 No. 4, pp. 519-542, doi: 10.1007/s11156-011-0241-4.

\section{Corresponding author}

Carlotta D’Este can be contacted at: carlotta.deste@unicatt.it

For instructions on how to order reprints of this article, please visit our website: www.emeraldgrouppublishing.com/licensing/reprints.htm

Or contact us for further details: permissions@emeraldinsight.com 